\title{
Taurine regulation of short term synaptic plasticity in fragile $X$ mice
}

\author{
Abdeslem El Idrissi ${ }^{1,2,3^{*}}$, Lorenz S Neuwirth ${ }^{2,3}$, William L'Amoreaux ${ }^{1,2,4}$ \\ From $17^{\text {th }}$ International Meeting of Taurine \\ Fort Lauderdale, FL, USA. 14-19 December 2009
}

\begin{abstract}
Background: Fragile $X$ Syndrome is the most common known genetic cause of autism. The Fmr1-KO mouse, lacks the fragile $X$ mental retardation protein (FMRP), and is used as a model of the syndrome. The core behavioral deficits of autism may be conceptualized either as excessive adherence to patterns as seen in repetitive actions and aberrant language, or as insensitivity to subtle but socially important changes in patterns. The hippocampus receives information from the entorhinal cortex and plays a crucial role in the processing of patterned information. To gain more insight into the physiological function of FMRP and the neuronal mechanisms underlying fragile $X$ syndrome, we examined the electrophysiological response of the hippocampus to pair pulse stimulation as a measure of patterned information processing and how it is affected in the Fmr $\mathrm{KO}$ mouse.
\end{abstract}

Methods: In this study, we used paired-pulse stimulation of the afferent perforant path and recorded from the CA1 region of the hippocampus. Two-month-old FVB/NJ male mice and age-matched Fmr1-KO mice were used in this study. Hippocampal slices were prepared, equilibrated in artificial cerebrospinal fluid (aCSF), and excitatory post synaptic potentials (EPSPs) measured by stimulating the perforant path of the dentate gyrus (DG) while recording from the molecular layer of CA1. Stimulation occurred by setting current and pulse width to evoke a fixed percentage of maximal EPSP amplitude. This stimulation paradigm allowed us to examine the processing capabilities of the hippocampus as a function of increasing interstimulus intervals (ISI) and how taurine, a GABA receptor agonist, affects such information processing.

Results: We found that hippocampal slices from wild type (WT) showed pair-pulse facilitation at ISI of 100-300 ms whereas slices from Fmr1-KO brains showed a consistent pair-pulse depression at a comparable ISI. Addition of $10 \mu \mathrm{M}$ taurine to $\mathrm{WT}$ slices resulted in a drastic decrease of the peak response to the second stimulus, resulting in an initial depression at $100 \mathrm{~ms}$ ISI followed by potentiation at higher ISI (150 ms and above). In the presence of taurine, the amplitude of the second response remained significantly lower than in its absence. Fmr1-KO mice however, were completely insensitive to taurine application and pair-pulse stimulation always resulted in a depression of the response to the second stimulus.

Conclusions: Previously we reported that Fmr1-KO mice have reduced beta subunits of the GABA receptors. We also showed as well as others that taurine acts as an agonist or a modulator for $G A B A_{A}$ receptors. Therefore, the insensitivity of Fmr1-KO slices to taurine application could be due to the reduced binding sites on the GABA $A$ receptors in the Fmr1-KO mice.

\footnotetext{
* Correspondence: Abdeslem.Elidrissi@csi.cuny.edu

'Department of Biology, College of Staten Island, The City University of New

York, 2800 Victory Boulevard, Staten Island, NY 10314, USA

Full list of author information is available at the end of the article
} 


\section{Background}

Fragile $\mathrm{X}$ is a common mental retardation syndrome that results from the silencing of a single gene, $F M R 1$, on the $\mathrm{X}$ chromosome [1,2]. The loss of the FMR1 gene product, FMRP, leads to mental retardation in males and to a range of deficits in heterozygous females. The syndrome has an autistic-like behavioral profile with hyper-arousal, self-stimulation, tactile-defensiveness and hypersensitivity to sensory stimuli $[1,3]$. There is also an increased prevalence of childhood seizures [4,5]. Physical features of the syndrome usually include enlarged testicles and prominent ears [4]. Neuroanatomical features include abnormal dendritic spine morphology [6-8], as well as alterations in the volume of the lateral ventricles and other structures [5,9]. FMRP is an RNA binding protein [10] that may act at the level of mRNA translation or translocation $[11,12]$.

The fragile $\mathrm{X}$ mouse model for this disorder was generated by insertional mutagenesis of the mouse Fmr 1 gene that eliminated expression of the mouse protein, Fmrp [3]. The fragile $\mathrm{X}$ mouse exhibits features that resemble elements of the fragile $X$ syndrome. These include enlarged testicles, mildly impaired learning behavior [3,13], an increased susceptibility to audiogenic seizures $[14,15]$, altered behaviors associated with anxiety [16] and abnormal dendritic spine morphology [17-19]. The increase in susceptibility to seizures and spine dysgenesis may be due to the role of Fmrp as an activity-dependent regulator of translation $[11,20,21]$. Increased seizure susceptibility may be related to increased group 1 metabotropic receptor (mGluR) response [22] and to reduced $\mathrm{GABA}_{\mathrm{A}}$ receptor expression [23]. In addition, long term depression (LTD) is enhanced in the fragile X mouse [24] and it has been proposed that this increase as well as spine dysgenesis are related to malfunction of a signaling cascade initiated by group 1 mGluRs in which Fmrp regulates translation of specific mRNAs [25].

Absence of Fmrp in the mouse model has also been shown to increase cerebellar LTD and to attenuate eye blink conditioning [26]. Analysis of the anterior piriform cortex showed reduced long term potentiation (LTP) in older animals [27]. No changes in paired pulse facilitation in hippocampal circuits have been noted when the interpulse interval was $40 \mathrm{~ms}$ [28] or 50 to $1600 \mathrm{~ms}$ [27]. However, these studies have examined the monosynaptic connections between the Schaffer collaterals and their postsynaptic target, the CA1 pyramidal cells. Here we have examined the integrative properties of the whole hippocampal formation and studied short-term plasticity within this structure and how it is affected by taurine.

\section{Methods}

Animals: All mice used in this study were two-monthold FVB/NJ males. Mice were housed in groups of three in a pathogen-free room, maintained on a $12 \mathrm{hr}$ light/ dark cycle and given food and water ad libitum. All procedures were approved by the Institutional Animal Care and Use Committee of the College of Staten Island/ CUNY, and were in conformity with the National Institutes of Health Guidelines. The number of mice sufficient to provide statistically reliable results was used in these studies.

Slice preparation: Hippocampal slices $(400 \mu \mathrm{m})$ were prepared using an automated Leica tissue chopper. Artificial cerebrospinal fluid (aCSF) consisted of the following composition (mM): $\mathrm{NaCl} 124, \mathrm{KCl} 3, \mathrm{CaCl}_{2} 2.4$, $\mathrm{MgSO}_{4} 1.3, \mathrm{NaH}_{2} \mathrm{PO}_{4} 1.25, \mathrm{NaHCO}_{3} 26$, and glucose 10 (gassed with $95 \% \mathrm{O}_{2} / 5 \% \mathrm{CO}_{2}, \mathrm{pH}=7.4$ ). Slices were prepared on ice-cold aCSF and calibrated for $45 \mathrm{~min}$ at room temperature (RT) in oxygenated aCSF prior to recording.

Recording and stimulation: Extracellular recordings of evoked excitatory postsynaptic potentials (EPSPs) were measured by placing the stimulating bipolar platinum electrodes in perforant path close to the suprapyamidal blade of the DG in the outer third of the molecular layer. Recording electrodes (tip impedance 1-5 M $\Omega$ ) were placed in the middle or outer region of the molecular layer of CA1 to record EPSPs. This stimulation paradigm allowed us to assess both the evoked responses and the overall integrative properties of the whole hippocampus. Stimulation parameters for test pulses $(0.05 \mathrm{~Hz})$ were standardized across slices by setting current and pulse width to evoke a fixed percentage of maximal EPSP amplitude in any given data set. Similarly, stimulus intensity for plasticity induction was standardized for all data sets. The stimulus current that produced about $40 \%$ of maximal responses (usually $100-150 \mu \mathrm{A}$ ) was used throughout the experiment for monitoring test pulses. Data were sampled and digitized at $100 \mathrm{kHz}$ with a band-pass filtered between $0.3 \mathrm{~Hz}$ and $3 \mathrm{kHz}$.

Statistical analysis: Statistical significance was determined by Student's $t$-test. Each value was expressed as the mean \pm SEM. Differences were considered statistically significant when the calculated $p$ value was less than 0.05 .

\section{Results}

\section{Altered short term plasticity in the hippocampus of fragile $X$ mice}

In the WT hippocampal slices, paired pulse stimulation at inter-stimulus intervals (ISI) of $100 \mathrm{~ms}$ and up to 
$300 \mathrm{~ms}$ consistently yielded facilitation as determined by the ratio of the evoked response to the second stimulus (p2) compared to the first stimulus (p1). On the other hand, stimulation of hippocampal slices from Fmr1-KO resulted in a consistent depression of the second evoked response at all ISI used (Figure 1). Although many factors could contribute to the observed electrophysiological differences between the WT and Fmr1-KO, alterations in the GABAergic system could be a contributing factor to these alterations in short term plasticity observed in the Fmr1-KO hippocampus. Consistent with this, bath application of taurine $(10 \mu \mathrm{M})$, a $\mathrm{GABA}_{\mathrm{A}}$ receptor agonist, resulted in a paired pulse depression of WT responses but not Fmr1-KO (Figure 1).

\section{Discussion}

We have previously shown that $\mathrm{GABA}_{\mathrm{A}}$ receptor expression is down-regulated [23] and cortical GABAergic interneurons are less abundant in Fmr1-KO mice $[29,30]$, suggesting reduced GABA signaling in these mice.

To assess electrophysiologically the functional significance of reduced expression of the $\mathrm{GABA}_{\mathrm{A}}$ and the alterations of the inhibitory system in the Fmr1-KO hippocampus, we performed electrophysiological recording from the CA1 region of the hippocampus after paired pulse stimulation of the perforant path. This allowed us to determine the overall integrative properties of neuronal circuits within the hippocampal formation.

The finding that Fmr1-KO mice have altered paired pulse facilitation indicates that the mechanism underlying short-term plasticity in the hippocampus is compromised (Figure 1). Several factors could be at the origin of these alterations. We have shown that the GABAergic inhibitory system is altered in these mice [23]. Additionally, we showed that the expression of somatostatin is down-regulated in Fmr1-KO mice [30]. Furthermore we showed that the reduced expression of this neuropeptide is consistent with both central and peripheral features of the fragile $\mathrm{X}$ syndrome.

There are several studies indicating the interaction of taurine with $\mathrm{GABA}_{\mathrm{A}}$ and glycine receptors acting as a modulator [31-36] or an agonist [37-44]. In heterologously expressed $\mathrm{GABA}_{\mathrm{A}}$ receptors composed of either $\alpha 1 \beta 3$ or $\alpha 1 \beta 3 \gamma 2$ subunits, taurine is a full or partial agonist, respectively, while both receptor types exhibit

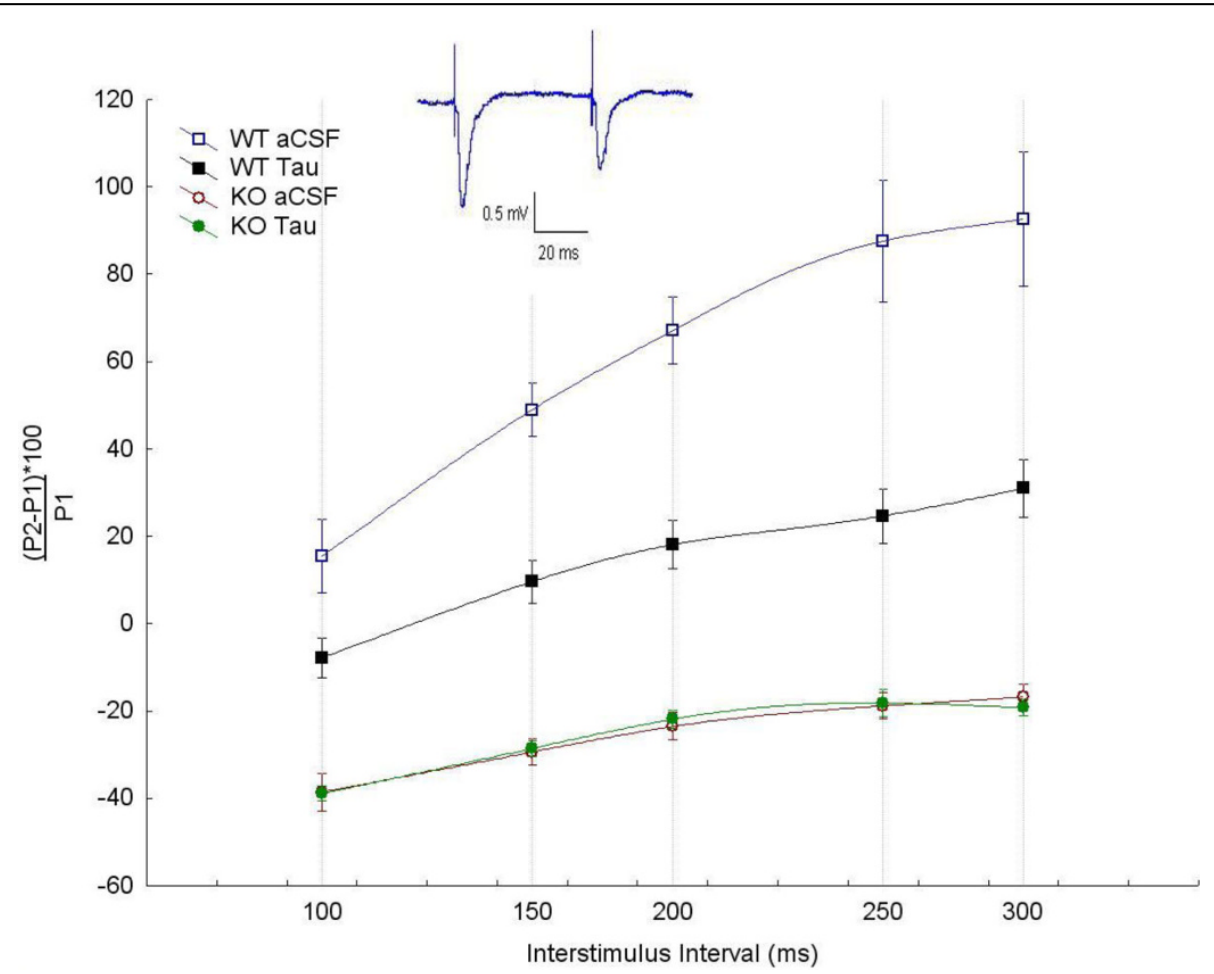

Figure 1 Altered paired pulse facilitation in the fragile $\mathbf{X}$ hippocampus Paired pulse stimulation at inter-stimulus intervals (ISI) of $100 \mathrm{~ms}$ and up to 300 ms consistently yielded facilitation as determined by the increase of the second EPSP (p2) compared to the first (p1). In Fmrp1KO slices, stimulation of the hippocampal slices from Fmr1-KO resulted in a consistent depression of the second evoked response at all ISI used. Application of taurine $(10 \mu \mathrm{M})$ resulted in a paired pulse depression of WT responses but not Fmr1-KO. Each data point represents mean \pm SEM of EPSP obtained following the paired pulse stimulation and expressed as [(p2-p1)/p1*100]. Data were obtained from 3 brains in each group and at least 5 slices per brain. 
similar taurine sensitivities [44]. Interestingly we found that the Fmr1-KO hippocampal slices are irresponsive to bath application of taurine. While in the WT mice, taurine addition resulted in a significant decrease in the amplitude of the facilitation; in the Fmr1-KO, pair pulse stimulation resulted in a consistent depression of the second evoked response and addition of taurine had no effect. Taurine is a $\mathrm{GABA}_{\mathrm{A}}$ receptor agonist and modulator [31-44]. Its application to hippocampal slices result in activation of $\mathrm{GABA}_{\mathrm{A}}$ receptors and hyperpolarization of $\mathrm{GABA}_{\mathrm{A}}$ receptors-expressing neurons, which comprises all principal cells of the hippocampus. This leads to reduced threshold for neuronal firing. Thus, under these conditions paired-pulse stimulation resulted, as expected, in a depression of neuronal response. The finding that slices from Fmr1-KO mice show abnormal pair pulse response and are insensitive to taurine indicates that the inhibitory GABAergic system is compromised in these mice and that the $\mathrm{GABA}_{\mathrm{A}}$ receptors expressed in these mice lack the binding site for taurine. Consistent with this we showed that Fmr1-KO mice have reduced $\beta$ subunit of the $\mathrm{GABA}_{\mathrm{A}}$ receptors and taurine could presumably bind to this subunit (L'Amoreaux and El Idrissi, 2010; this volume). Furthermore, disrupting the gene for $\beta 3$ subunit of the $\mathrm{GABA}_{\mathrm{A}}$ receptor in mice produces electroencephalographic abnormalities, seizures, learning and memory deficits, poor motor skills on a repetitive task and hyperactivity features all common to fragile $\mathrm{X}$ syndrome [45]. Beta 3 subunit phosphorylation acts as a regulatory switch to control cycling of $\mathrm{GABA}_{\mathrm{A}}$ receptors into and out of the plasma membrane [45]. This may allow neurons to specifically modify cell surface receptor insertion and/or endocytosis rates to control the efficacy of inhibitory synaptic transmission. The finding that Fmr1-KO mice have reduced $\beta$ subunit of the $\mathrm{GABA}_{\mathrm{A}}$ receptors may explain the abnormal response to pair pulse stimulation and the insensitivity to taurine application.

\section{Conclusions}

Fmr1-KO mice have altered GABAergic system. Here, we show electrophysiologically that alterations in the GABAergic system may underlie the abnormal response to pair pulse stimulation, the cellular analogue of shortterm plasticity. Furthermore, we showed that taurine regulates short-term plasticity in the hippocampus. Taurine application to slices resulted in a shift from pair pulse facilitation to pair pulse depression in WT but not Fmr1-KO mice presumably lacking the binding site for taurine on $\mathrm{GABA}_{\mathrm{A}}$ receptors.

\section{Acknowledgements}

The authors wish to acknowledge funding from FRAXA Foundation (AEI), the Professional Staff Congress of CUNY (AEI and WJL), the Louis Stokes Alliance for Minority Participation (LSAMP - NSF, LSN), the Alliance for Graduate Education and the Professoriate (AGEP-NSF, LSN), The Center for Developmental Neuroscience (LSN), and the National Science Foundation for funds for the purchase of the confocal microscope (DBI0421046). This article has been published as part as part of Journal of Biomedical Science Volume 17 Supplement 1, 2010: Proceedings of the 17th International Meeting of Taurine. The full contents of the supplement are available online at http://www.jbiomedsci.com/supplements/17/S1.

\section{Author details}

${ }^{1}$ Department of Biology, College of Staten Island, The City University of New York, 2800 Victory Boulevard, Staten Island, NY 10314, USA. ²Doctoral Program in Biology - Neuroscience, The Graduate Center, The City University of New York, 365 Fifth Avenue, New York, NY 10016, USA. ${ }^{3}$ Center for Developmental Neuroscience, College of Staten Island, The City University of New York, 2800 Victory Boulevard, Staten Island, NY 10314, USA. ${ }^{4}$ Advanced Imaging Facility, College of Staten Island, The City University of New York, 2800 Victory Boulevard, Staten Island, NY 10314, USA.

\section{Authors' contributions}

AEl conceived of the study, designed the study, performed electrophysiological recordings, the statistical analysis and drafted the manuscript. LSN assisted in the dissections, recording and data processing. WJL participated in the study design as well as edited the manuscript. All authors read and approved the final manuscript.

\section{Competing interests}

The authors have no competing interests.

Published: 24 August 2010

\section{References}

1. Bardoni $B$, Mandel $J$ : Advances in understanding of fragile $X$ pathogenesis and FMRP function, and in identification of $X$ linked mental retardation genes. Curr Opin Genet Dev 2002, 12:284-293.

2. O'Donnell WT, Warren ST: A decade of molecular studies of fragile $X$ syndrome. Annu Rev Neurosci 2002, 25:315-338.

3. Bakker CE, Verheij C, Willemsen R, Vanderhelm R, Oerlemans F, Vermey M, Bygrave A, Hoogeveen AT, Oostra BA, Reyniers E, et al: Fmr1 knockout mice: a model to study fragile X mental retardation. Cell 1994, 78:23-33.

4. Hagerman RJ, Miller LJ, McGrath-Clarke J, Riley K, Goldson E, Harris SW, Simon J, Church K, Bonnell J, Ognibene TC, Mclntosh DN: Influence of stimulants on electrodermal studies in Fragile $\mathrm{X}$ syndrome. Microsc Res Tech 2002, 57:168-173.

5. Wisniewski KE, Segan SM, Miezejeski CM, Sersen EA, Rudelli RD: The Fra(X) syndrome: neurological, electrophysiological, and neuropathological abnormalities. Am J Med Genet 1991, 38:476-480.

6. Hinton VJ, Brown WT, Wisniewski K, Rudelli RD: Analysis of neocortex in three males with the fragile X syndrome. Am J Med Genet 1991, 41:289-294.

7. Irwin SA, Idupulapati M, Gilbert ME, Harris JB, Chakravarti AB, Rogers EJ, Crisostomo RA, Larsen BP, Mehta A, Alcantara CJ, et al: Dendritic spine and dendritic field characteristics of layer $\mathrm{V}$ pyramidal neurons in the visual cortex of fragile-X knockout mice. Am J Med Genet 2002, 111:140-146.

8. Irwin SA, Patel B, Idupulapati M, Harris JB, Crisostomo RA, Larsen BP, Kooy F, Willems PJ, Cras P, Kozlowski PB, et al: Abnormal dendritic spine characteristics in the temporal and visual cortices of patients with fragile-X syndrome: a quantitative examination. Am J Med Genet 2001, 98:161-167.

9. Reiss AL, Abrams MT, Greenlaw R, Freund L, Denckla MB: Neurodevelopmental effects of the FMR-1 full mutation in humans. Nat Med 1995, 1:159-167.

10. Siomi H, Siomi MC, Nussbaum RL, Dreyfuss G: The protein product of the fragile $X$ gene, FMR1, has characteristics of an RNA-binding protein. Cell 1993, 74:291-298.

11. Brown V, Jin P, Ceman S, Darnell JC, O'Donnell WT, Tenenbaum SA, Jin X, Feng $Y$, Wilkinson KD, Keene JD, et al: Microarray identification of FMRPassociated brain mRNAs and altered mRNA translational profiles in fragile $X$ syndrome. Cell 2001, 107:477-487.

12. Jin P, Zarnescu DC, Ceman S, Nakamoto M, Mowrey J, Jongens TA, Nelson DL, Moses K, Warren ST: Biochemical and genetic interaction 
between the fragile $\mathrm{X}$ mental retardation protein and the microRNA pathway. Nat Neurosci 2004, 7:113-117.

13. Kooy RF, D'Hooge R, Reyniers E, Bakker CE, Nagels G, De Boulle K, Storm K Clincke G, De Deyn PP, Oostra BA, Willems PJ: Transgenic mouse model for the fragile X syndrome. Am J Med Genet 1996, 64:241-245.

14. Chen $\mathrm{L}$, Toth M: Fragile $\mathrm{X}$ mice develop sensory hyperreactivity to auditory stimuli. Neuroscience 2001, 103:1043-1050.

15. Musumeci SA, Bosco P, Calabrese G, Bakker C, De Sarro GB, Elia M, Ferri R, Oostra BA: Audiogenic seizures susceptibility in transgenic mice with fragile X syndrome. Epilepsia 2000, 41:19-23.

16. Peier AM, Nelson DL: Instability of a premutation-sized CGG repeat in FMR1 YAC transgenic mice. Genomics 2002, 80:423-432.

17. Braun $K$, Segal M: FMRP involvement in formation of synapses among cultured hippocampal neurons. Cereb Cortex 2000, 10:1045-1052.

18. Galvez R, Greenough WT: Sequence of abnormal dendritic spine development in primary somatosensory cortex of a mouse model of the fragile X mental retardation syndrome. Am J Med Genet A 2005, 135:155-160.

19. Nimchinsky EA, Oberlander AM, Svoboda K: Abnormal development of dendritic spines in FMR1 knock-out mice. J Neurosci 2001, 21:5139-5146.

20. Li Z, Zhang Y, Ku L, Wilkinson KD, Warren ST, Feng Y: The fragile $X$ mental retardation protein inhibits translation via interacting with mRNA. Nucleic Acids Res 2001, 29:2276-2283.

21. Miyashiro KY, Beckel-Mitchener A, Purk TP, Becker KG, Barret T, Liu L, Carbonetto S, Weiler IJ, Greenough WT, Eberwine J: RNA cargoes associating with FMRP reveal deficits in cellular functioning in Fmr1 null mice. Neuron 2003, 37:417-431.

22. Chuang SC, Zhao W, Bauchwitz R, Yan Q, Bianchi R, Wong RK: Prolonged epileptiform discharges induced by altered group I metabotropic glutamate receptor-mediated synaptic responses in hippocampal slices of a fragile X mouse model. J Neurosci 2005, 25:8048-8055.

23. El Idrissi A, Ding XH, Scalia J, Trenkner E, Brown WT, Dobkin C: Decreased $\mathrm{GABA}(\mathrm{A})$ receptor expression in the seizure-prone fragile $X$ mouse. Neurosci Lett 2005, 377:141-146.

24. Huber KM, Gallagher SM, Warren ST, Bear MF: Altered synaptic plasticity in a mouse model of fragile $X$ mental retardation. Proc Natl Acad Sci U S A 2002, 99:7746-7750.

25. Bear MF, Huber KM, Warren ST: The mGluR theory of fragile $X$ mental retardation. Trends Neurosci 2004, 27:370-377.

26. Koekkoek SK, Yamaguchi K, Milojkovic BA, Dortland BR, Ruigrok TJ, Maex R, De Graaf W, Smit AE, VanderWerf F, Bakker CE, et al: Deletion of FMR1 in Purkinje cells enhances parallel fiber LTD, enlarges spines, and attenuates cerebellar eyelid conditioning in Fragile $X$ syndrome. Neuron 2005, 47:339-352.

27. Larson J, Jessen RE, Kim D, Fine AK, du Hoffmann J: Age-dependent and selective impairment of long-term potentiation in the anterior piriform cortex of mice lacking the fragile $\mathrm{X}$ mental retardation protein. $J$ Neurosci 2005, 25:9460-9469.

28. Paradee W, Melikian HE, Rasmussen DL, Kenneson A, Conn PJ, Warren ST: Fragile $X$ mouse: strain effects of knockout phenotype and evidence suggesting deficient amygdala function. Neuroscience 1999, 94:185-192.

29. Selby L, Zhang C, Sun QQ: Major defects in neocortical GABAergic inhibitory circuits in mice lacking the fragile $\mathrm{X}$ mental retardation protein. Neurosci Lett 2007, 412:227-232.

30. El Idrissi A, Boukarrou L, Dokin C, Brown WT: Taurine improves congestive functions in a mouse model of fragile $\mathrm{X}$ syndrome. Adv Exp Med Biol 2009, 643:191-198

31. Elldrissi A, Trenkner E: Taurine as a modulator of excitatory and inhibitory neurotransmission. Neurochem Res 2004, 29:189-197.

32. Cascio M: Modulating Inhibitory Ligand-Gated Ion Channels. AAPS J 2006, 8:E353-E361.

33. Frosini M, Sesti C, Dragoni S, Valoti M, Palmi M, Dixon HBF, Machetti F, Sgaragli G: Interactions of taurine and structurally related analogues with the GABAergic system and taurine binding sites of rabbit brain. $\mathrm{Br} J$ Pharmacol 2003, 138:1163-1171.

34. Frosini M, Sesti C, Saponara S, Ricci L, Valoti M, Palmi M, Machetti F, Sgaragli G: A specific taurine recognition site in the rabbit brain is responsible for taurine effects on thermoregulation. Br J Pharmacol 2003, 139:487-494.
35. Malminen O, Kontro P: Modulation of the GABA-benzodiazepine receptor complex by taurine in rat brain membranes. Neurochem Res 1986, 11:85-94.

36. Ochoa-de la Paza LD, Martínez-Dávilaa IA, Miledia RMartínez-Torres A: Modulation of human GABAp1 receptors by taurine. Neurosci Res 2008, 61:302-308.

37. Jia F, Yue M, Chandra D, Keramidas A, Goldstein PA, Homanics GE, Harrison NL: Taurine Is a Potent Activator of Extrasynaptic GABA $A$ Receptors in the Thalamus. J Neurosci 2008, 28(z):106-115.

38. Hussy N, Deleuze C, Pantaloni A, Desarmenien MG, Moos F: Agonist action of taurine on glycine receptors in rat supraoptic magnocellular neurones: possible role in osmoregulation. J Physiol 1997, 502:609-621.

39. Sergeeva OA, Haas HL: Expression and function of glycine receptors in striatal cholinergic interneurons from rat and mouse. Neuroscience 2001, 104:1043-1055

40. Wang F, Xiao C, Ye JH: Taurine activates excitatory non-synaptic glycine receptors on dopamine neurones in ventral tegmental area of young rats. J Physiol 2005, 565:503-516.

41. Cunningham JR, Neal MJ: Effect of gamma-aminobutyric acid agonists, glycine, taurine and neuropeptides on acetylcholine release from the rabbit retina. J Physiol 1983, 336:563-577.

42. del Olmoa N, Bustamanteb J, del Ríoa RM, Solís JM: Taurine activates $\mathrm{GABA}_{A}$ but not $\mathrm{GABA}_{B}$ receptors in rat hippocampal $C A 1$ area. Brain Res 2000, 864:298-307.

43. Mori M, Gähwiler BH, Gerber U: Beta-Alanine and taurine as endogenous agonists at glycine receptors in rat hippocampus in vitro. J Physiol 2002, 539:191-200.

44. Dominguez-Perrot $C$, Feltz $P$, Poulter MO: Recombinant $G A B A_{A}$ receptor desensitization: the role of the gamma 2 subunit and its physiological significance. J Physiol 1996, 497:145-159.

45. DeLorey TM, Handforth A, Anagnostaras SG, Homanics GE, Minassian BA, Asatourian A, Fanselow MS, Delgado-Escueta A, Ellison GD, Olsen RW: Mice lacking the beta 3 subunit of the $G A B A_{A}$ Receptor have the epilepsy phenotype and many of the behavioral characteristics of Angelman Syndrome. J Neurosci 1998, 18:8505-8514.

doi:10.1186/1423-0127-17-S1-S15

Cite this article as: El Idrissi et al.: Taurine regulation of short term synaptic plasticity in fragile X mice. Journal of Biomedical Science 201017 (Suppl 1):S15.

\section{Submit your next manuscript to BioMed Central and take full advantage of:}

- Convenient online submission

- Thorough peer review

- No space constraints or color figure charges

- Immediate publication on acceptance

- Inclusion in PubMed, CAS, Scopus and Google Scholar

- Research which is freely available for redistribution

Submit your manuscript at www.biomedcentral.com/submit
Biomed Central 